\title{
PENGARUH KUALITAS SUMBER DAYA INSANI, KUALITAS PELAYANAN PETUGAS PEMADAM KEBAKARAN DAN FASILITAS TERHADAP KEPUASAN MASYARAKAT KABUPATEN TANAH DATAR
}

\author{
Elsha Afrida Puja Opjame ${ }^{1 *}$, Zainuddin ${ }^{2)}$, Elsandra Eka Putra ${ }^{3)}$ \\ Dinas Satpol PP dan Pemadam Kebakaran Kabupaten Tanah Datar ${ }^{1)}$ \\ Institut Agama Islam Batusangkar'2) \\ Widyaiswara Muda Pada Badan Diklat Provinsi Sumatera Barat \\ Jalan Kinantan (Samping Telkom) Batusangkar \\ Corespondent Author*) \\ Email: elshaafridapujao@gmail.com
}

\begin{abstract}
Abstrak: Kualitas pelayanan publik merupakan sebuah indikator utama dalam penyelenggaraan pemerintahan yang baik, mulai pemerintah pusat hingga pemerintah daerah. Pelayanan yang diberikan pemerintah daerah seperti Pemadam Kebakaran Kabupaten Tanah Datar. Pokok permasalahan dalam penelitian ini dilihat dari indikator kepuasan masyarakat Kabupaten Tanah Datar terhadap pelayanan yang diberikan oleh petugas pemadam kebakaran. Penelitian ini menggunakan teknik menggunakan pendekatan kuantitatif yang nerupakan metode untuk menguji beberapa teori dengan meneliti hubungan antara variabel-variabel dengan sampel sebanyak 88 responden. Pengambilan sampel dengan menggunakan teknik random sampling. Teknik analisis data dengan menggunakan analisis regresi berganda, uji validitas, uji realibitas, uii t, uji f, dan uji asumsi klasik. Hasil penelitian menunjukkan bahwa kualitas sumber daya insani berpengaruh signifikan terhadap kepuasan masyarakat, kualitas pelayanan petugas pemadam kebakaran menunjukkan pengaruh signifikan terhadap kepuasan masyarakat dan fasilitas berpengaruh signifikan terhadap kepuasan masyarakat. Kualitas sumber daya insani, kualitas pelayanan pemadam kebakaran dan fasilitas berpengaruh secara srimultan terhadap kepuasan masyarakat Kabupaten Tanah Datar.
\end{abstract}

Kata Kunci: SDI, Kualitas Pelayanan, Fasilitas dan Kepuasan Masyarakat.

Abstract: The quality of public services is a major indicator of good governance, from the central government to local governments. Services provided by local governments such as the Tanah Datar Regency Fire Department. The main problem in this study is the indicator of community satisfaction in Tanah Datar Regency with the services provided by firefighters. This study uses a quantitative approach which is a method to test several theories by examining the relationship between variables with a sample of 88 respondents. Sampling using random sampling technique. The data analysis technique used multiple regression analysis, validity test, reliability test, uii $t, f$ test, and classical assumption test. The results showed that the quality of human resources had a significant effect on community satisfaction, the quality of fire fighting services showed a significant effect on community satisfaction and facilities had a significant effect on community satisfaction. The quality of buman resources, the quality of fire fighting services and facilities have a simultaneous effect on the satisfaction of the people of Tanah Datar Regency

Keyword: SDI, Service Quality, Facilities and Community Satisfaction 


\section{PENDAHULUAN}

Perkembangan dan kemajuan organisasi tidak akan lepas dari peranan sumber daya insani yang akan mengelola, mengendalikan dan mengatur segala kegiatan demi tercapainya tujuan organisasi. Sumber daya insani merupakan sistem-sistem formal dalam sebuah organisasi untuk memastikan penggunaan bakat manusia secara efektif dan efisien guna mencapai tujuan organisasi (Mathis dan Jackson, 2012, p.67).

Sumber daya insani yang dibutuhkan oleh masyarakat adalah mereka yang memiliki etos kerja tinggi, jujur, disiplin, memiliki kepercayaan diri, bekerja karena Allah SWT dan mampu memberikan pelayanan kepada masyarakat. Salah satunya kualitas pelayanan yang diberikan oleh Dinas Pemadam Kebakaran kepada masyarakat Kabupaten Tanah Datar.

Petugas pemadam kebakaran dituntut selalu siap, tanggap dan siaga ketika bertugas dalam menghadapi kejadian bencana kebakaran. Adapun bencana kebakaran yang terjadi disebabkan oleh arus pendek dengan presentase 58\%, disusul 19\% karena membakar sampah, dan yang terendah dikarenakan lampu minyak/lilin dan punting rokok/obat nyamuk masing-masing sebesar 1\%. Dari data tersebut penyebab kejadian kebakaran paling besar disebabkan oleh arus pendek yang biasanya terjadi di gedung, sekolah, ataupun rumah. Oleh karena itu sudah seharusnya dilakukan pencegahan lebih dini agar tidak terjadi kebakaran. Selain faktor manusia, kebakaran juga disebabkan oleh alam seperti gempa bumi, letusan gunung berapi, kekeringan dan lain sebagainya. (BPBD Tanah Datar, 2016)

Berdasarkan data yang diperoleh dari Pemerintah Daerah Kabupaten Tanah didapatkan bahwa dari tahun 2015 sampai tahun 2016 meningkat sebanyak 31 kali kejadian. Pada tahun 2017 mengalami penurunan kebakaran sebanyak 96 kali.

Dalam pelaksanaan operasional petugas pemadam kebakaran, menghadapi masalah seperti hambatan mulai dari posko hingga ke lokasi kebakaran yang disebabkan oleh masyarakat yang berada di lokasi yang hanya datang menonton sering menghambat kerja petugas, dan lokasi kejadian yang sulit dijangkau karena akses jalan terlalu kecil sehingga mobil pemadam kebakaran sulit masuk ke lokasi. Fasilitas yang masih kurang seperti mobil pemadam kebakaran, dimana kondisi mobil pemadam kebakaran yang sudah tua dan rusak ringan, kurangnya Alat Pelindung Diri (APD) seperti seperti helem, masker, sarung tangan dan sepatu harvik (Wawancara, Suradi, 2018).

Dari uraian latar belakang dan kondisi daerah di atas, maka peneliti melakukan penelitian untuk melihat seberapa besar pengaruh kualitas sumber daya insani, kualitas pelayanan petugas pemadam kebakaran dan fasilitas yang memadai dengan prediksi apakah ada pengaruh atau tidaknya terhadap kepuasan masyarakat Kabupaten Tanah Datar. Penelitian ini dituangkan dalam bentuk karya ilmiah dengan judul "Pengaruh Kualitas Sumber Daya Insani, Kualitas Pelayanan Petugas Pemadam Kebakaran, dan Fasilitas Terbadap Kepuasan Masyarakat Kabupaten Tanah Datar".

Kata kepuasan (satisfaction) berasal dari bahasa Latin "satis" yang berarti memadai, cukup baik dan "factio" yang berarti melakukan atau membuat. Kepuasan dapat bermakna sebagai "upaya atau usaha untuk memenuhi sesuatu" atau "membuat sesuatu memadai". (Tjiptono dan G. Chandra, 2005, p.195)

Kepuasan berhubungan dengan adanya tingkat kepercayaan masyarakat terhadap organisasi publik. Menurut Harbani Pasolong "Semakin baik kepemerintahan dan kualitas pelayanan yang diberikan, maka semakin tinggi kepercayaan masyarakat (high trust)". Kepercayaan masyarakat akan semakin tinggi 
apabila masyarakat mendapatkan pelayanan yang baik dan merasa puas dengan pelayanan tersebut.

Kepuasan masyarakat menyangkut harapan terhadap kinerja organisasi publik yang dirasakan. Tingkat kepuasan merupakan fungsi dari perbedaan antara kinerja yang dirasakan (perceived performance) dan harapan (expectation). Apabila kinerja di bawah harapan, masyarakat akan merasa tidak puas. Apablia kinerja sesuai dengan harapan, masyarakat akan merasa puas. Apabila kinerja melampaui harapan, tentunya masyarakat akan merasa sangat puas, senang, atau bahagia.

Pembahasan tentang sumber daya insani dimulai dari penciptaan manusia sebagai makhluk dengan sebaik-baik bentuk dibandingkan makhluk Allah SW'T yang lainnya dengan diberikan akal pikiran dan hawa nafsu. Sebagaimana firman Allah surat At Tiin ayat 4:

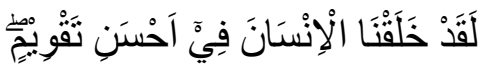
Sesunggubnya kami telah menciptakan manusia dengan sebaik-baiknya (Qs At-Tin: 4)

Manusia dibekali hawa nafsu dan akal untuk berpikir sebelum bertindak, sehingga ia bebas menentukan jalan mana yang akan dipilih, jalan yang diilhamkan kepadanya. Potensi lain yang dimiliki manusia adalah rasio/ pemikiran, kalbu/hati, ruh/jiwa dan jasmani/raga.

Sumber daya insani didefinisikan sebagai individu yang merancang dan memproduksi keluaran (output) dalam rangka pencapaian strategi dan tujuan yang ditetapkan oleh suatu organisasi. Dalam Islam, sumber daya insani didasari pada konsep bahwa setiap karyawan adalah manusia bukan mesin dan bukan semata menjadi sumber daya bisnis (Wirawan, 2015, p.21).

Sumber daya insani adalah salah satu faktor yang berperan penting bahkan tidak dapat dilepaskan dari sebuah organisasi baik institusi maupun pemerintah. Pada hakikatnya berupa manusia yang diperkejakan sebagai penggerak, pemikir, dan perencana untuk mencapai tujuan organisasi.

Pelayanan menurut Kotler yaitu tindakan atau kegiatan yang bisa ditawarkan oleh salah satu pihak kepada pihak lain yang pada dasarnya tidak berwujud dan tidak mengakibatkan kepemilikan apapun (Kotler, 2011).

Kasmir mengatakan bahwa "pelayanan diberikan sebagai tindakan atau perbuatan seseorang atau organisasi untuk memberikan kepuasan kepada pelanggan”. Tindakan itu dilakukan dengan cara berhadapan langsung dengan pelanggan atau menempatkan sesuatu sehingga konsumen sudah mengetahui tempat atau pelayanan secara tidak langsung (Kasmir, 2011).

Jadi pelayanan ditujukan sebagai tindakan yang menciptakan banyak manfaat bagi pelanggan dengan mewujudkan perubahan yang diinginkan dalam diri atau atas nama penerima. Pelayanan memiliki nilai tersendiri bagi pelanggan erat kaitannya dengan penciptaan nilai pelanggan. Kualitas pelayanan mencakup kondisi yang berhubungan dengan seberapa jauh pihak penyedia jasa mampu sesuai dengan harapan pelanggannya. Berdasarkan kaitannya dengan Dinas Pemadam Kebakaran Kabupaten Tanah Datar sebagai penyedia jasa pelayanan diharapkan mampu memberikan pelayanan yang prima dan menyenangkan bagi masyarakat.

Untuk mempermudah pencapaian tujuan organisasi dibutuhkan alat atau sarana yang dapat mendukung aktivitas atau kegiatan sehari-hari di organisasi seperti tersedianya fasilitas. Kata fasilitas berasal dari bahasa Belanda "facilient" yang berarti prasarana atau wadah untuk melakukan atau mempermudah sesuatu (Samsudin, 2009, p.47).

Fasilitas merupakan segala hal yang memberi kemudahan dan kelancaran

Pengaruh Kualitas Sumber: ... 58 
terlaksananya serta memudahkan kegiatan yang dapat berupa sarana dan prasarana. Menurut Kamus Besar Bahasa Indonesia "fasilitas adalah sarana melancarkan pelaksanaan fungsi. (KBBI, 2008:389)

Dari uraian di atas apat disimpulkan bahwa fasilitas kerja adalah segala sesuatu yang berupa sarana atau alat yang digunakan untuk mempermudah aktivitas kerja sehingga kegiatan operasional dapat terlaksana.

\section{METODE PENELITIAN}

Jenis penelitian yang peneliti lakukan adalah dengan menggunakan pendekatan kuantitatif yang nerupakan metode untuk menguji beberapa teori dengan meneliti hubungan antara variabel-variabel (Juliansyah Noor, 2011:38). Variabel yang mempengaruhi dalam penelitian ini adalah kualitas sumber daya insani $\left(\mathrm{X}_{1}\right)$, kualitas pelayanan petugas pemadam kebakaran $\left(X_{2}\right)$ dan fasilitas $\left(X_{3}\right)$. Variabel yang dipengaruhi yaitu kepuasan masyarakat $(\mathrm{Y})$.

Populasi dalam penelitian ini adalah masyarakat yang pernah mengalami kebakaran sebanyak 112 korban dari tahun 2017 sampai tahun 2018 dan sampel penelitian sebanyak 88 sampel.

Teknik pengambilan sampel dalam penelitian ini menggunakan random sampling sehingg didapatkan Kecamatan Lima Kaum sebanyak 25 responden, Tanjung Emas 17 responden, X Koto sebanyak 10 responden, Rambatan sebanyak 9 responden, Batipuh sebanyak 9 orang, Lintau Buo sebanyak 8 responden, Lintau Buo Utara sebanyak 7 responden dan Salimpaung sebanyak 3 responden.

Pengembangan instrumen pada penelitian ini dengan menggunakan skala likert dengan melihat atau mengukur setuju atau tidak setujunya responden terhadap beberapa pernyataan yang mengukur suatu obyek penelitian yang nantinya akan digunakan scoring dari jawaban responden.

Teknik analisis data dalam penelitian ini yaiu dengan menggunakan uji validitas dan uji reliabilitas. Uji hipotesis dilakukan ujivregresi linear berganda dengan menggunakan rumus: $\mathrm{Y}=\mathrm{a}+\mathrm{b}_{1} \mathrm{X}_{1}+\mathrm{b}_{2} \mathrm{X}_{2}+\mathrm{b}_{3} \mathrm{X}_{3}+\mathrm{e}, \mathrm{Y}$ adalah kepuasan masyarakat, a adalah Nilai Konstanta, $\mathrm{b}_{1}$ adalah koofesien regresi kualitas sumber daya insani, $\mathrm{b}_{2}$ adalah koofisien regresi kualitas pelayanan, $b_{3}$ adalah koofisien regresi fasilitas, $\mathrm{X}_{1}$ adalah kualitas sumber daya insani, $\mathrm{X}_{2}$ adalah kualitas pelayanan dan $\mathrm{X}_{3}$ adalah fasilitas. Uji $f$, berguna untuk melihat kemampuan menyeluruh dari variabel bebas yaitu $\mathrm{X}_{1}, \mathrm{X}_{2}$, dan $\mathrm{X}_{3}$ sehingga dapat menjelaskan keragaman variabel terikat $(\mathrm{Y})$. Kemudian, Uji Signifikan Parsial (Uji-t), digunakan untuk mengetahui apakah suatu variabel bebas $(\mathrm{X})$ berpengaruh nyata atau tidak nyata terhadap variabel terikat. (Purwanto 2004:525).

Selanjutnya, Uji Asumsi Klasik dengan menggunakan:

a. Uji Asumsi Klasik Multikoliniearitas

Dikatakan terjadi multikolineritas jika koofisien korelasi antar variabel bebas lebih kecil atau sama dengan $0,60(\mathrm{r} \leq 0,60)$

b. Uji Asumsi Klasik Heteroskedasitas

Apabila residualnya variannya sama disebut Hemoskedasitas. Apabila variansinya tidak sama disebut heteroskedasitas. Persamaan regresi yang baik yaitu tidak terjadi heteroskedasitas. (Imam Ghozali, 2013, p.105)

c. Uji Asumsi Klasik Normalitas

Persamaan regresi dikatakan baik apabila mempunyai data variabel bebas (X) dan data variabel terikat (Y) berdistribusi mendekati normal. 


\section{HASIL PENELITIAN}

\section{Deskripsi Data}

Data dalam penelitian ini dikumpulkan dan diperoleh dari hasil penyebaran kuesioner kepada responden. Jenis kuesioner yang digunakan adalah kuesioner tertutup dimana responden hanya memilih jawaban yang tersedia. Kuesioner ini terdiri dari 28 pernyataan untuk variabel kepuasan masyarakat, 6 pernyataan untuk variabel kualitas sumber daya insani, 11 pernyataan untuk variabel kualitas pelayanan petugas pemadam kebakaran dan8pernyataan untuk variabel fasilitas.

Peneliti menggunakan sampel 88 responden, yang tersebar dalam 7 kecamatan yang paling banyak mengalami kebakaran di wilayah Kabupaten Tanah Datar yaitu: Lima Kaum, Tanjung Emas, X Koto, Rambatan, Batipuh, Lintau Buo, Lintau Buo Utara, dan Salimpaung.

Uji validitas

\section{Validitas Kepuasan Masyarakat}

Validitas uji instrumen kepuasan masyarakat yang terdiri dari 28 butir pernyataan dan sampel sebanyak 88 responden. Lalu data diolah dengan perhitungan SPSS versi 21.

Dari tabel validitas kepuasan masyarakat diperoleh nilai valid yang terdapat dalam kolom "Corrected Item Total Correlation" $\left(\mathrm{r}_{\mathrm{xy}}\right)$ menunjukan $\mathrm{r}_{\text {hitung }}$ lebih besar dari $\mathrm{r}_{\text {tabel }}$ sebesar 0,177 (dengan taraf signifikan $5 \%$ dan $n=88-2=86)$, dapat disimpulkan bahwa item-item dari pernyataan kepuasan masyarakat dinyatakan valid.

\section{Validitas Kualitas Sumber Daya} Manusia

Hasil uji validitas kualitas sumber daya insani dalam penelitian ini pada tabel menunjukan $r_{\text {hitung }}$ lebih besar dari $r_{\text {tabel }}$ sebesar 0,177 (dengan taraf signifikan 5\% dan $\mathrm{n}=88-2=86$ ), dapat disimpulkan bahwa item-item dari pernyataan kualitas sumber daya insani dinyatakan valid.

\section{Validitas Kualitas Pelayanan Petugas Pemadam Kebakaran}

Hasil uji validitas kualitas pelayanan petugas pemadam kebakaran dalam penelitian ini terdapat pada tabel menunjukan $\mathrm{r}_{\text {hitung }}$ lebih besar dari $\mathrm{r}_{\text {tabel }}$ sebesar 0,177 (dengan taraf signifikan 5\% dan $\mathrm{n}=88-2=86$ ), disimpulkan bahwa item-item dari pernyataan kualitas pelayanan petugas pemadam kebakaran dinyatakan valid.

\section{Validitas Fasilitas}

Validitas uji instrumen fasilitas yang terdiri dari 8 butir pernyataan dilakukan dengan penghitungan SPSS versi 21. Hasil uji validitas fasilitas terdapat pada tabel menunjukan $\mathrm{r}_{\text {hitung }}$ lebih besar dari $r_{\text {tabel }}$ sebesar 0,177 (dengan taraf signifikan $5 \%$ dan $\mathrm{n}=88-2=86$ ), dapat disimpulkan bahwa item dari pernyataan fasilitas dinyatakan valid.

\section{Uji Realibitas}

1. Realibitas Kepuasan Masyarakat Kabupaten Tanah Datar

Dari tabel, hasil uji reliabilitas dapat dilihat pada nilai cronbach's alpha, jika nilai cronbach's alpha $>0,60$ maka item pernyataan dinyatakan reliabel. Dapat disimpulkan bahwa item-item dari pernyataan kepuasan masyarakat dinyatakan reliabel.

2. Realibitas Kualitas Sumber Daya Insani Dari tabel, hasil uji reliabilitas dapat dilihat pada nilai cronbach's alpha, jika nilai cronbach's alpha $>0,60$ maka item pernyataan dinyatakan reliabel. Sehingga dapat disimpulkan bahwa item-item dari 
pernyataan kualitas sumber daya insani dinyatakan reliabel.

3. Realibitas Kualitas Pelayanan Petugas Pemadam Kebakaran

Dari hasil uji reliabilitas yang dapat dilihat pada nilai cronbach's alpha, jika nilai cronbach's alpha $>0,60$ maka item pernyataan dinyatakan reliabel. Dapat disimpulkan bahwa item-item dari pernyataan kualitas pelayanan petugas pemadam kebakaran dinyatakan reliabel.

4. Reliabilitas Fasilitas

Dari tabel hasil uji reliabilitas dapat dilihat pada nilai cronbach's alpha, jika nilai cronbach's alpha $>0,60$ maka item pernyataan dinyatakan reliabel. Dapat disimpulkan bahwa item-item dari pernyataan fasilitas dinyatakan reliabel.

\section{Regresi Linear Berganda}

Pada tabel unstandardized coefficients pada kolom B pada constant adalah 23,228 sedangkan nilai kualitas sumber daya insani 0,469, kualitas pelayanan petugas pemadam kebakaran 1,522 dan fasilitas 0,312. Persamaan regresi nya dapat ditulis: $\mathrm{Y}=\alpha+\mathrm{b}_{1} \mathrm{x}_{1}+\mathrm{b}_{2} \mathrm{x}_{2}+\mathrm{b}_{3} \mathrm{x}_{3}+\mathrm{e}$ atauY $=$ $23,228+0,469+1,522+0,312+$ e. Persamaan ini dapat diterjemahkan

a. Konstanta sebesar 23,228 menunjukan bahwa ketika variabel independen kualitas sumber daya insani, kualitas pelayanan petugas pemadam kebakaran dan fasilitas konstan, maka rata-rata kepuasan masyarakat sebesar 23,228.

b. Koefisien regresi kualitas sumber daya insani0,469, menunjukan bahwa setiap kenaikan 1 konstanta pada variabel kualitas sumber daya insani, maka akan meningkatkan kepuasan masyarakat sebesar 0,469. Koefisien regresi bernilai positif menunjukan bahwa semakin baik kualitas sumber daya insani, maka semakin baik kepuasan masyarakat.

61 | Jurnal Tamwil, Vol. VII, No. 1 Januari-Juni 2021 c. Koefisien regresi kualitas pelayanan petugas pemadam kebakaran1,522, menunjukan bahwa setiap kenaikan 1 konstanta pada variabel kualitas pelayanan petugas pemadam kebakaran, maka akan meningkatkan kepuasan masyarakat sebesar 1,522 Koefisien regresi bernilai positif menunjukan bahwa semakin baik kualitas pelayanan petugas pemadam kebakaran, maka semakin baik kepuasan masyarakat.

d. Koefisien regresi fasilitas 0,312, menunjukan setiap kenaikan 1 konstanta pada variabel fasilitas, maka akan meningkatkan kepuasan masyarakat sebesar 0,312. Koefisien regresi bernilai positif menunjukan bahwa semakin baik fasilitas, maka semakin baik kepuasan masyarakat.

\section{Hasil Uji t}

Dari hasil uji t yang dilakukan diperoleh bahwa:

a. Pengaruh kualitas sumber daya insani terhadap kepuasan masyarakat

Dapat dilihat bahwa nilai thitung untuk variabel kualitas sumber daya insaniyaitu 1,734, pada tabel 1,664 dengan degree of freedom (df)84 dan taraf signifikan 0,05. Karena $\mathrm{t}_{\text {hitung }}(1,734)>\mathrm{t}_{\text {tabel }}(1,664)$ maka $\mathrm{H}_{0}$ ditolak dan $\mathrm{H}_{\mathrm{a}}$ diterima. Sehingga dapat diartikan variabel kualitas sumber daya insani mempunyai pengaruh signifikan terhadap kepuasan masyarakat.

b. Pengaruh kualitas pelayanan petugas pemadam kebakaran terhadap kepuasan masyarakat

Dapat dilihat bahwa nilai thitung untuk variabel kualitas pelayanan petugas pemadam kebakaranyaitu 6,824 , pada $t_{\text {tabel }}$ 1,664 dengan degree of freedom (df) 84 dan taraf signifikan 0,05 . Karena thitung $(6,824)$ $>t_{\text {tabel }}(1,664)$ maka $\mathrm{H}_{0}$ ditolak dan $\mathrm{H}_{\mathrm{a}}$ diterima. Sehingga dapat diartikan variabel kualitas pelayanan petugas pemadam 
kebakaran mempunyai pengaruh signifikan terhadap kepuasan masyarakat.

c. Pengaruh fasilitas terhadap kepuasan masyarakat

Dapat dilihat bahwa nilai thitung untuk variabel fasilitasyaitu 1,822, pada $t_{\text {tabel }}$ 1,664 dengan degree of freedom (df) 84 dan taraf signifikan 0,05 . Karena thitung $(1,822)$ $>t_{\text {tabel }}(1,664)$ maka $\mathrm{H}_{0}$ ditolak dan $\mathrm{H}_{\mathrm{a}}$ diterima. Sehingga dapat diartikan variabel fasilitas mempunyai pengaruh signifikan terhadap kepuasan masyarakat.

\section{Uji $\mathbf{f}$}

Dapat dilihat pada tabel $f$ nilai $f_{\text {hitung }}$ yaitu 27,252 , sedangkan nilai $\mathrm{f}_{\text {tabel }} 2,71$ yang diperoleh dengan menggunakan tabel $\mathrm{f}$ dengan derajat bebas/degree of freedom (df) residual yaitu 84 sebagai penyebut, dandegree of freedom( $\mathrm{df})$ regression yaitu 3 sebagai pembilang dengan taraf signifikan 0,05 , sehingga diperoleh nilai $\mathrm{f}_{\text {hitung }}(27,252)>\mathrm{f}_{\text {tabel }}(2,71)$ maka $\mathrm{H}_{0}$ ditolak dan $\mathrm{H}_{\mathrm{a}}$ diterima. Berdasarkan nilai signifikan, terlihat pada kolom sig yaitu 0,000 ini berarti probabilitas 0,000 lebih $<$ dari pada 0,05 maka $\mathrm{H}_{0}$ ditolak dan $\mathrm{H}_{2}$ diterima. Berarti variabel kualitas sumber daya insani, kualitas pelayanan petugas pemadam kebakaran dan fasilitas secara simultan berpengaruh signifikan terhadap kepuasan masyarakat.

\section{Uji Multikolinieritas}

Berdasarkan hasil pengujian dari tabel, diketahui nilai VIF kualitas sumber daya insani yaitu 1,305, nilai kualitas pelayanan petugas pemadam kebakaran yaitu 1,277 dan nilai fasilitas yaitu 1,043. Karena nilai VIF untuk semua variabel tersebut $<10$ maka dapat disimpulkan tidak terjadi gangguan multikolinieritas atau dengan kata lain model regresi ini terbebas dari gejala multikolinieritas.

\section{Uji Heteroskedasitas}

Dari tabel diketahui kualitas sumber daya insani mempunyai nilai signifikan 0,571 , kualitas pelayanan petugas pemadam kebakaran 0,148 dan fasilitas 0,628 yang mana $>0,05$ maka tidak terjadi gejala heteroskedastisitas.

\section{Uji Asumsi Klasik Normalitas}

Didapatkan hasil kolmogorov smirnov $\mathrm{Z}$ dari tabel yaitu: variabel kualitas sumber daya insani sebesar 1,885, kualitas pelayanan petugas pemadam kebakaran sebesar 1,111, fasilitas sebesar 1,594 dan kepuasan masyarakat sebesar 0,802 yang mana semua variabel $>0,05$ maka data berdistribusi normal.

Grafik histogram dan normal probability plot dapat dilihat pada gambar di bawah ini:

\section{Hasil Uji Normalitas}

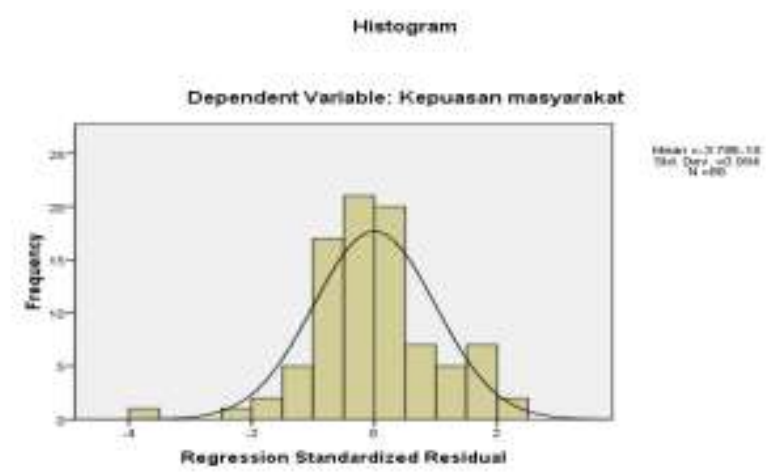

\section{Hasil Uji Normal Probability Plot}

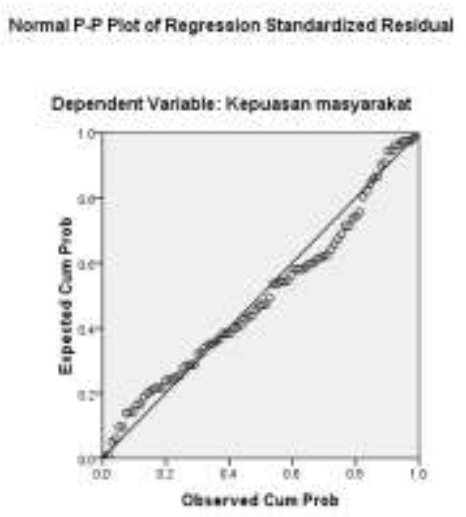

Dari hasil histogram didapatkan garis kurva normal dan grafik normal probability plot menunjukan berdistribusi normal karena garis 
atau titik-titik mengikuti garis diagonal dan tidak menyebar.

\section{PENUTUP}

Berdasarkan hasil penelitian dapat disimpulkan sebagai berikut. Pertama, kualitas sumber daya insani mempunyai pengaruh signifikan terhadap kepuasan masyarakat Kabupaten Tanah Datar, artinya Pemadam Kebakaran Kabupaten Tanah Datar perlu untuk meningkatkan kualitas sumber daya insani yang dimiliki, sehingga dapat meningkatkan kualitas pelayanan yang diberikan kepada masyarakat. Sumber daya insani sebagai unsur terpenting sumber daya penggerak suatu proses dalam organisasi. Unsur lain dalam organisasi seperti fasilitas, alat-alat, metode dan teknik kegiatan dapat didayagunakan oleh manusia demi keberlangsungan dan kemajuan organisasi.

Kedua, kualitas pelayanan petugas pemadam kebakaran mempunyai pengaruh signifikan terhadap kepuasan masyarakat Kabupaten Tanah Datar, artinya pelayanan yang baik akan memberikan kepuasan kepada masyarakat Kabupaten Tanah Datar.

Fasilitas mempunyai pengaruh signifikan terhadap kepuasan masyarakat Kabupaten Tanah Datar artinya dengan tersedianya Fasilitas yang lengkap akan memberi kemudahan dan kelancaran terlaksananya operasional dengan memanfaatkan sarana dan prasarana yang dimiliki. Kualitas sumber daya insani, kualitas pelayanan petugas pemadam kebakaran dan fasilitas secara simultan berpengaruh signifikan terhadap kepuasan masyarakat Kabupaten Tanah Datar. Kepuasan masyarakat tergantung dari pelayanan yang diberikan oleh petugas pemadam, sehingga masyarakat Kabupaten Tanah Datar mengharapkan adanya pemenuhan pelayanan dari petugas pemadam dengan tersedianya semua fasilitas yang memadai dan masyarakat merasakan kepuasan.

\section{DAFTAR KEPUSTAKAAN}

BPBD Tanah Datar (2016)

Fandy, Tjiptono. 2011. Service Management Mewujudkan Layanan Prima. Edisi 2. Yogyakarta: Andi Offset

Ghozali, Imam. (2013). Aplikasi Analisis Multivariat dengan Program IBM SPSS 21. Edisi 7, Semarang: Universitas Diponegoro

Husein Umar. (2011). Riset Sumber Daya Manusia. Jakarta: Gramedia Pustaka Utama

Kasmir. (2011). Etika Customer Service. Jakarta: PT Rajagrafindo Persada

Kotler, Philip. (2011). Manajemen Pemasaran. Edisi Keempat Belas. Jakarta: Indeks

Mathis, R.L. \& J.H. Jackson. (2012). Human Resource Management: Manajemen Sumber Daya Manusia. Terjemahan Dian Angelia. Jakarta: Salemba Empat

Noor Juliansyah. (2011). Metodologi Penelitian. Jakarta: Kencana Prenada Media Group

Purwanto, Suhardi (2004). Statistika untuk. Ekonomi dan Kenangan Modern. Buku kedua. Jakarta: Salemba Empat

Samsudin S, (2009). Manajemen Sumber Daya Manusia. Bandung: Pustaka Setia

Sugiyono. (2014). Metode Penelitian Pendidikan Pendekatan Kuantitatif dan Kualitatif. Bandung: Alfabeta.

Tim Redaksi KBBI PB. (2008). Kamus Besar Bahasa Indonesia (Edisi Keempat) Jakarta: Pusat Bahasa Departemen Pendidikan Nasional

Wirawan. (2015). Manajemen Sumber Daya Manusia Indonesia. Jakarta: PT Raja Grafindo Persada

Patmawati. (2008). Pembangunan Ekonomi Melalui Agihan Zakat: Tinjauan Empirical. Shariah Journal, Vol. 16 (2), 223-244.

Pembayun, E. L. (2013). One Stop Qualitative of Research Methodology in Communication. Jakarta: Lentera Printing . 
Tim Emir. (2016). Panduan Zakat Terlengkap. Jakarta: Emir.
Zuhaili, W. A. (2011). Fiqib Islam Wa adillatubu 3 (1 ed). (B. Permadi, Ed., \& A. H. Kattani, Trans.) Jakarta: Gema Insani. 